\title{
Memórias consignadas: reflexões sobre arquivos literários
}

[ Consigned memories: reflections on literary archives

\section{Cleber Araújo Cabral ${ }^{\mathbf{I}}$}

Texto elaborado com o apoio da bolsa de Pós-doutorado Júnior do CNPq (I52803/20I6-5).

[MARQUES, Reinaldo. Arquivos literários - teorias, histórias, desafios. Belo Horizonte: Ed. UFMG, 2OI5, $228 \mathrm{p}$.

A existência de instituições dedicadas à custódia de arquivos de escritores no Brasil é relativamente recente, assim como o crescente aumento de pesquisas afetadas pelo "feitiço dos arquivos" que recorrem à diversidade de materiais (fotografias, manuscritos, obras de arte, objetos pessoais, recortes) alocados nesses espaços de memória literária. Como consequências dessas incursões deram-se, no campo dos estudos literários, além da publicação de biografias, de correspondências e de obras inéditas, a elaboração da crítica genética, a revitalização de disciplinas como a história, a crítica e a teoria literárias, bem como o retorno inovador da crítica biográfica.

CABRAL, Cleber Araújo. Memórias consignadas: reflexões sobre arquivos literários. Revista do Instituto de Estudos Brasileiros, Brasil, n. 66, p. 246-249, abr. 2017.

DOI: http://dx.doi.org/Io.II606/issn.23I6-90IX.voi66p246-249

I Universidade Federal de Minas Gerais (UFMG, Belo Horizonte, MG, Brasil). 
Não são poucas as publicações em livros e periódicos que, desde o início da década de I990, reúnem artigos e ensaios que tratam sobre arquivos pessoais, notadamente os de escritores. Contudo, nenhuma delas se dedicou, exclusivamente, a apresentar o esboço da gênese dessas instituições no Brasil ou a refletir acerca dos impactos teóricos e metodológicos exercidos pelo uso de tal documentação nos estudos literários.

A fim de preencher essa lacuna, Reinaldo Marques, pesquisador do Acervo de Escritores Mineiros e professor do Programa de Pós-Graduação em Estudos Literários da Faculdade de Letras da UFMG, publicou Arquivos literários - teorias, histórias, desafios, em 20I5, pela Editora da UFMG. De acordo com o autor, os trabalhos buscam delinear "algumas peculiaridades da empreitada prática e teórica do trabalho com arquivos dos escritores” (p. Io), reportando a uma espécie de work in progress pertinente à definição do arquivo literário (termo que aparece nos títulos de quatro dos nove ensaios) como objeto epistemológico. Ao optar por dispor os textos em seriação cronológica invertida - do mais recente, de 20I4, ao mais remoto, que data de 2000 -, o autor oferta aos leitores a possibilidade de acompanhar o desenvolvimento, a maturação e a reelaboração das indagações, das propostas e dos questionamentos que perpassam o volume e que culminam na criação do conceito que dá título à obra. Como se Marques buscasse apresentar ao leitor, sob ângulos diversos, um arranjo narrativo do movimento "tateante, com idas e vindas", rumo aos bastidores de suas reflexões, à maneira da "gênese exibicionista", observada nas correspondências de escritores.

Em escrita fluida, que conjuga a imaginação construtiva, a atividade especulativa e o trânsito entre saberes (como teoria literária, direito, filosofia, história e política), Marques investiga como o deslocamento do acervo do escritor, do espaço privado para o público, resulta em sua metamorfose em arquivo literário. Assim operam-se complexos processos de desterritorialização e reterritorialização, advindos do tratamento que esse arquivo sofre por parte de saberes especializados - arquivologia, biblioteconomia e museologia - que o afetam substancialmente em termos espaciais, organizacionais, operacionais, simbólicos e conceituais. Disso resulta um arquivo de caráter misto, que deixa de ser privado sem se tornar, absolutamente, público.

A título de visão panorâmica do livro - pois, conforme lembra o autor, "é 
impossível totalizar o arquivo" (p. II) -, os nove ensaios reunidos, além de apresentar a especificidade dos arquivos literários, discutem os rumos da disciplina Literatura Comparada no século XXI e as imagens do escritor que se projetam por meio dos arquivos literários. Figura instigante e que faz as vezes de duplo do autor é o "anarquivista". Personagem de matiz nietzschiana e benjaminiana, "combinação paradoxal de arquivista e anarquista”, este atua como "má consciência” necessária ao pesquisador que intenta ler o arquivo a contrapelo. Ciente "de que o documento é também uma montagem, ao mesmo tempo verdade e mentira", o anarquivista, espécie de "demônio da teoria", convoca o pesquisador a "instaurar uma anomia no arquivo", de modo a reconfigurar a ordem de significados estabelecida pela arquivística tradicional, a fim de oportunizar deslocamentos da "história literária e cultural hegemônica, formulando outras leituras e interpretações” (p. 68).

Não poderiam faltar, no volume, relatos ilustrativos das incursões de Marques em acervos literários. Exemplos disso podem ser lidos no percurso pela coleção de peças do Caribe, de cunho erótico, presentes no arquivo de Oswaldo França Júnior (objetos que explicitariam a heterogeneidade da cultura latino-americana, uma vez que representariam a permanência de fragmentos das culturas e das tradições orais no âmbito da cultura letrada); pela interpretação de retratos feitos por pintores contemporâneos de Murilo Rubião, de Cyro dos Anjos e de Lúcia Machado de Almeida, tendo em vista a elaboração das representações de escritores como rito de construção da identidade autoral; pelo trabalho com a (monumental) correspondência travada entre os poetas Abgar Renault e Carlos Drummond de Andrade; pelo processo de organização e de edição do volume que contém a poesia traduzida por Henriqueta Lisboa; além do (desventurado) empreendimento de publicação do "diário alemão" de Guimarães Rosa - projeto interditado pela família do escritor.

Mas, dentre todos os textos do livro, cabe destaque para o denso "Arquivos literários, entre o público e o privado" - não por ser o mais extenso, mas pelo fato de que, nele, encontram-se sintetizadas as principais questões que instigam Marques e que, de acordo com sua proposta, colaboram para a especificidade dos arquivos literários. Nas cinco partes desse ensaio, encontram-se: a importância dos trabalhos de Michel Foucault e Jacques Derrida para e redefinição do estatuto epistemológico dos arquivos; as imbricações entre a literatura, a formação do Estado e a identidade nacional; a archival turn, mudança de paradigma ocorrida no âmbito da arquivologia ao início dos anos 1990, que colabora para a desnaturalização dos arquivos, fazendo com que estes passem a ser vistos não enquanto depósitos de provas do passado, mas como parte do processo de construção de discursos sobre o passado; os conflitos entre interesses privados e públicos atuantes na conformação dos arquivos pessoais e dos arquivos públicos; as tensões entre o direito de acesso à informação e o direito de privacidade; os problemas referentes aos direitos autorais e a suas implicações na pesquisa com documentos pessoais; os impactos e as potencialidades das tecnologias digitais nas práticas de arquivamento.

Arquivos literários é, sem dúvida, uma publicação que apresenta rica colaboração em termos teóricos e práticos para repensar campos tão diversos como os estudos literários, a biografia, a história institucional, o patrimônio cultural e, naturalmente, 
os arquivos pessoais. Não consiste exagero considerar que o livro já se constitui obra de referência fundamental.

SOBRE O AUTOR

CLEBER ARAÚJO CABRAL é doutor em Teoria da Literatura e Literatura Comparada e mestre em Teoria da Literatura pela Universidade Federal de Minas Gerais (UFMG), onde atua como pesquisador do Núcleo de Estudos dos Acervos de Escritores Mineiros.

E-mail: clabrac1980@gmail.com 